\title{
Acúmulo de fluido intra-uterino em éguas cobertas no cio do potro*
}

\author{
ALEXANDRE SCHILELA \\ Rodrigo Costa Mattos (Orientador - UFRGS) \\ Banca: Carlos Antonio Mondino Silva (UFSM), Eduardo Medici (URCAMP), Ricardo Macedo Gregory (UFRGS)
}

O objetivo do presente trabalho foi determinar: (1) se o acúmulo de fluido intra-uterino (FIU) durante o cio do potro pode influenciar a frequiência de acúmulo de FIU após a cobertura; (2) se o acúmulo de FIU durante o cio do potro pode prejudicar as taxas de prenhez; (3) se tratamentos em éguas com acúmulo de FIU durante o cio do potro diminui a incidência de FIU após a cobertura e melhora os índices de prenhez; (4) se éguas não cobertas no cio do potro apresentam maiores índices de prenhez no cio subseqüente e (5) se lavagens uterinas realizadas após a cobertura podem melhorar as taxas de prenhez de éguas cobertas no cio do potro. Foram utilizadas éguas Puro Sangue de Corrida com idades variando entre 3 e 23 anos. Todos os partos foram controlados e, quando necessário, foi realizada vulvoplastia. A partir do $5^{\circ}$ dia pósparto, as éguas foram examinadas através de palpação retal e ultra-sonografia, em intervalos inferiores a 48 horas, para verificar o crescimento folicular, o grau de edema uterino e a presença de FIU. As éguas foram cobertas quando um folículo com diâmetro maior que 40mm foi detectado, associado com a redução do edema uterino. Novo exame foi realizado 36 a 48 horas após a cobertura para confirmar a ovulação e verificar a condição uterina. Todas as éguas que apresentaram FIU 36 a 48 horas após a cobertura foram submetidas a lavagens uterinas seguidas de uma aplicação endovenosa de $20 \mathrm{UI}$ de ocitocina. O diagnóstico de gestação foi realizado 12 a 14 dias após a ovulação. Perdas gestacionais observadas entre o primeiro diagnóstico de gestação e os 42 dias de prenhez foram consideradas como morte embrionária (ME). Quatro experimentos foram realizados. De cinqüenta e sete éguas que apresentaram FIU durante o cio do potro, 35,1\% apresentaram FIU após a ovulação, resultado superior $(\mathrm{p}<0,05)$ ao verificado em éguas que não retiveram FIU durante o cio do potro $(n=73 ; 15,1 \%)$. Os índices de prenhez das éguas com presença de FIU durante o cio do potro não diferiram significativamente $(\mathrm{p}>0,05)$ dos das éguas que não apresentaram FIU. Tratamentos com ocitócicos em éguas com FIU durante o cio do potro não diminuíram a incidência de FIU pós-cobertura, nem melhoraram os índices de prenhez, em comparação com as éguas não tratadas. As taxas de prenhez aos 14 dias em éguas que apresentaram FIU durante o cio do potro não diferiram significativamente $(\mathrm{p}>0,05)$ entre as éguas não tratadas, as cobertas no segundo cio e as submetidas a lavagens 6 a $8 \mathrm{~h}$ após a cobertura. Entretanto, observou-se diferença significativa $(\mathrm{p}<0,05)$ nos índices de prenhez aos 42 dias entre as éguas submetidas a lavagens 6 a $8 \mathrm{~h}$ após a cobertura e aquelas não tratadas. A prenhez obtida em éguas com FIU pós-cobertura $(n=31)$, submetidas a lavagens uterinas realizadas entre 36 e 48 horas após a cobertura, foi significativamente inferior $(\mathrm{p}<0,05)$ à verificada nas éguas sem FIU após a cobertura $(\mathrm{n}=99 ; 74,7 \%)$. Os resultados obtidos permitem concluir que: ocorre uma maior incidência de FIU após a cobertura no cio do potro em éguas apresentando FIU durante o cio do potro; a presença de FIU durante o cio do potro não afeta o índice de prenhez; tratamentos com ocitócicos em éguas apresentando FIU durante o cio do potro não diminuem a incidência de FIU no período pós-cobertura, nem melhoram os índices de prenhez; lavagens uterinas realizadas 6 a 8 horas após a cobertura no cio do potro melhoram os resultados de prenhez aos 42 dias; os índices de prenhez no cio do potro são semelhantes aos obtidos no cio subseqüente; lavagens uterinas realizadas 36 a 48h após a cobertura em éguas com FIU após o cio do potro não aumentam as taxas de prenhez.

Descritores: eqüinos, cio do potro, lavagens uterinas, ocitócicos, fluido intra-uterino.

Apresentada: 27 novembro 2002

\footnotetext{
* Dissertação de Mestrado nº 340 (Especialidade: Fisiopatologia da Reprodução). 43f. Programa de Pós-graduação em Ciências Veterinárias da Faculdade de Veterinária - UFRGS, Porto Alegre/RS. CORRESPONDÊNCIA: A. Schilela [saveh@terra.com.br].
} 


\title{
Intra-uterine fluid accumulation in mares bred at the foal heat**
}

\author{
ALEXANDRE SCHILELA \\ Rodrigo Costa Mattos (Adviser - UfRGS) \\ Committee: Carlos Antonio Mondino Silva (UFSM), Eduardo Medici (URCAMP), Ricardo Macedo Gregory (UFRGS)
}

The objectives of the present study were determine: (1) if IUF accumulation during foal-heat can influence the frequency of IUF accumulation after breeding; (2) if intra-uterine fluid (IUF) accumulation during foal-heat can impair pregnancy rates; (3) if treatments in mares with IUF during foal heat decreased IUF after breeding and improved pregnancy; (4) if mares that not bred during foal-heat show increased pregnancy rates in the subsequent cycle and (5) if uterine flushes performed after breeding can increase pregnancy rates in mares bred during foal-heat. Thoroughbred mares aged 3 and 23 years were studied. All births were assisted and, when necessary, perineum repair was immediately performed. From day 5 postpartum, mares were examined by means of rectal palpation and ultrasound per rectum, at intervals $£ 48 \mathrm{~h}$, in order to evaluate follicular growth, grade of uterine edema and presence of IUF. Mares were allowed to bred when a follicle $340 \mathrm{~mm}$, associated with a reduced grade of uterine edema was found. Another reproductive examination was performed $36-48 \mathrm{~h}$ after breeding in order to confirm ovulation and to evaluate the uterine state. All mares showing IUF 36-48h after breeding were submitted to uterine flushes followed by $20 \mathrm{IU}$ oxytocin i.v. Pregnancy diagnosis was performed 12-14 days after ovulation. Pregnancy losses occurring between the first diagnosis detection of pregnancy and the $42^{\text {th }}$ day of pregnancy were recorded as embryonic death (ED). Four experiments were performed. From fifty-seven mares presenting with IUF during foal-heat; $35.1 \%$ retained fluid after ovulation. This result was superior $(p<0.05)$ to that found in mares that did not retain fluid during foal-heat $(n=73 ; 15.1 \%)$. Pregnancy rates were not significantly $(p>0,05)$ different between mares presenting and without IUF during foal-heat. Treatments with oxytocics in mares with IUF during foal-heat were not effective, neither decreasing the incidence of post-breeding IUF, nor improving pregnancy rates, in comparison to not treated mares. Pregnancy rates on Day 14 in mares that presented with IUF during the foal-heat were not significantly different $(p>0,05)$ between control mares, mares bred at second heat and mares submitted to uterine flushes $6-8 \mathrm{~h}$ after breeding. A significant difference $(\mathrm{p}<0,05)$ between control and flushed mares, 6-8 h after breeding, was found regarding pregnancy rates on Day 42. Uterine flushing performed $36-48 \mathrm{~h}$ after breeding in mares with post-breeding IUF $(\mathrm{n}=31)$ did not provide satisfactory pregnancy rates $(48.4 \%)$, results being significantly inferior $(\mathrm{p}<0.05)$ than those observed in mares without post-breeding IUF ( $n=99 ; 74.7 \%)$. It was concluded that the presence of IUF during foal-heat does not affect pregnancy rate. A higher incidence of IUF after breeding at foal-heat can be expected in mares presenting with IUF during the foal-heat. It was also detected that treatments with oxytocics in mares presenting with IUF during foal-heat neither decrease the incidence of post-breeding IUF, nor improve pregnancy rates. Uterine flushes performed 6-8 $\mathrm{h}$ after breeding at the foal-heat improves pregnancy rate at 42 days The pregnancy rate during foal-heat is not different from pregnancy rate in subsequent cycle. Uterine flushing performed $36-48 \mathrm{~h}$ after breeding in mares with IUF after foal heat ovulation did not improve pregnancy rates.

Key words: equine, foal-heat, uterine lavage, oxytocics, intra-uterine fluid.

\footnotetext{
** Master's Thesis no. 340 (Field: Theriogenology). 43p. Postgraduate Program in Veterinary Sciences, Faculdade de Veterinária, Universidade Federal do Rio Grande do Sul (UFRGS), Porto Alegre/Brazil. CORRESPONDENCE: A. Schilela [saveh@terra.com.br].
} 